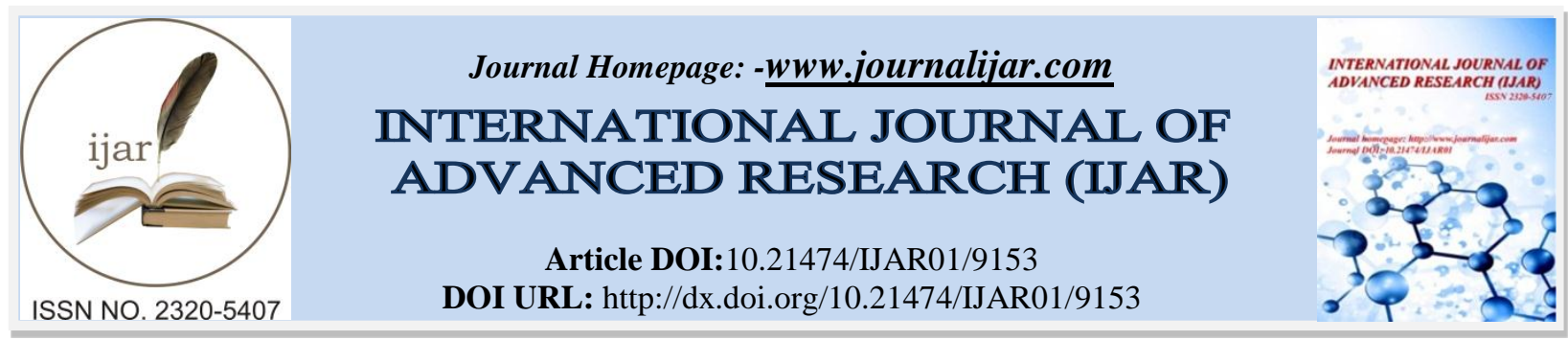

RESEARCH ARTICLE

\title{
ACETYLATION OPTIMIZATION OF SAGO (METROXYLON SAGU ROTT) STARCH FOR EDIBLE FILM PRODUCTION.
}

\author{
Rosniyati Suwarda ${ }^{1,3}$, Tun Tedja Irawadi ${ }^{2}$, Prayoga Suryadarma ${ }^{3}$ And Indah Yuliasih ${ }^{3}$. \\ 1. Maluku Assessment Institute for Agricultural Technology (Maluku AIAT), Indonesia. \\ 2. Departement of Chemistry, Bogor Agricultural University, Dramaga, Bogor-West Java, Indonesia. \\ 3. Departement of Agroindustrial Technology, Bogor Agricultural University, Dramaga, Bogor-West Java, \\ Indonesia.
}

\section{Manuscript Info}

(.........................

Manuscript History

Received: 24 March 2019

Final Accepted: 26 April 2019

Published: May 2019

Key words:-

Acetylation; contact angle; edible film; sago starch; sago starch acetate; optimization;; tensile strength.

\section{Abstract}

Optimization of sago starch acetylation on tensile strength and contact angle of the edible film was investigated using response surface methodology. The operating conditions were the concentrations of acetic acid anhydride, reaction time and $\mathrm{pH}$. The only concentration of acetic acid anhydride and $\mathrm{pH}$ value had a significant effect on tensile strength and contact angle. Both acid concentration and $\mathrm{pH}$ value had a negative effect on tensile strength, however, had a positive effect on contact angle. The optimum condition of acetylation for tensile strength and contact angle of edible film sago starch acetate was $44 \%$ acetic acid anhydride concentration at $\mathrm{pH} 8.24$ and reaction time of 60 minutes. This combination yields $2.80 \mathrm{MPa}$ tensile strength and contact angle $42.18^{\circ}$ of edible film sago starch acetate.

Copy Right, IJAR, 2019,. All rights reserved.

\section{Introduction:-}

Sago (Metroxylon sp.) is a tropical plant that grows in Southeast Asia with a sago forest area of around 20 million Ha spread across the Asia-Pacific region (Karim et al. 2008). Approximately 47\% of the world's sago plants can be found in Indonesia (Oates and Hicks, 2002). Sago-producing regions in Indonesia include Riau, Sulawesi, Maluku and Papua (Abner and Miftahorrahman, 2002). Sago starch production ranges from 25 tons/ha/year which is 3-4 times higher than rice, corn, wheat, and 17 times higher than cassava (Karim et al. 2008). Sago starch generally used as functional ingredient in the food industry such as thickener, stabilizer and gelling agent.

Meanwhile, starch (polysaccharide) has been widely used as an alternative raw material for making edible films because it is biodegradable, easy to obtain, low prices and environmentally friendly also increasing consumer demand for safe food (food grade) (De Azeredo, 2012). In addition, starch can form a film that has good characteristics such as strong, transparent, easy to be modified in its properties (Teressa and Silva, 2011).

Edible film and coating components are divided into three groups, namely, hydrocolloids (starch, protein, cellulose, alginate, and polysaccharides), lipids (waxes, glycerol, and fatty acids) and composites (a mixture of lipid and hydrocolloid components). Wax (carnauba wax, beeswax, paraffin wax) has been applied commercially as a protective layer for fresh fruits and vegetables since the 1930s to block water vapor transport, reduce abrasion, increasing integrity and controlling the composition of internal gases (Kester and Fennema, 1986). Wax coatings are

Corresponding Author:-Rosniyati Suwarda.

Address:-Maluku Assessment Institute for Agricultural Technology (Maluku AIAT), Indonesia. 
more resistant to water vapor transport than other lipid or nonlipid coatings. However, lipid-based coatings produce a more oily surface (Guilbert, 1986), low permeability of O2, CO2, and ethylene (Baldwin, 1994). Also, wax coatings are difficult to obtain because it is expensive and petroleum-based waxes are non-edible and toxic. This indicates that starch is a potential alternative material in the development of edible films and coatings.

The requirement of starch as edible film, it should have high amylose content (30\%) (Bae et al. 2008). Amylose composition of several types of sago starch from Maluku are quite high compared to sago starch from other regions including sago tuni (Metroxylon rumphii Mart.), Ihur (M. sylvestre Mart.), and molat (M. sagu Rott.) (Polnaya et al 2008). The high amylose composition in the three types of sago starch has great potential to be explored in the development of edible films and coatings. Starch-based films such as sago starch have low barrier properties to moisture due to their hydrophilic properties (Mali et al. 2005). To increase the strength of the film, the desired film should have low water absorption.

The low hydrophobicity can cause edible films and coatings to easily absorb water vapor and cause the growth of microorganisms, such as fungal growth on the surface of the film, and reduce the stability of the film (Garcia et al. 2011). This can shorten the shelf life of the coated product. The hydrophobicity of edible film and sago starch-based coatings can be improved by increasing starch substitution (DS) by acetylation. However, the increase in DS values can reduce the tensile strength of edible films. The reactant concentration, temperature, reaction time, particle size and characteristics of native granule structure will affect the amount of DS starch produced (Sun and Sun, 2002; Huang et al. 2007). Also, catalyst concentrations also contribute to the value of DS produced (Tupa et al. 2015). DS values for edible films ranged from 0.01 - 0.2 (Matti et al. 2004). Methylated starch has superior physical-chemical properties such as gelatinization temperature, swelling power, solubility, and high clarity of pasta and has better storage and cooking stability than native starch (Sodhi and Singh, 2005). Therefore, the purpose of this study was to investigate the characteristics of sago starch as an edible film and to obtain the optimum condition of the acetylation process in improving its hydrophobicity.

\section{Materials and Methods:-}

Materials and Reagents. The raw material used in this study was sago starch (Metroxylon sagu Rott.) obtained from Ambon, Maluku. The chemicals used include acetic acid anhydride (Ajax Chemical)), sodium hydroxide (Merck), chloric acid (Merck), ethanol (Merck), glycerol (Merck), phenol red (Merck) and aquadest.

\section{Characterisation of sago starch :}

Sago starch characterization data includes physicochemical analysis of moisture, ash, protein, fat, and amylose content (AOAC, 1995), granule size determined by SEM, functional analysis including solubility of swelling power, clarity of paste, freeze-thaw stability (Perez et al. 1999) and amylographic properties.

\section{Starch Acetylation.}

The acetylation procedure was performed according to the Wurzburg method (1964). The desired DS value is 0.01 0.20 , to obtain the degree of substitution (DS) value, the treatment of reactant concentration (44-88\%), reaction time (30-60 minutes) and $\mathrm{pH}(7.5-8.5)$ was investigated. The parameters observed were percent acetyl content and degree of substitution (DS) determined according to Whistler and Daniel (1995).

\section{Preparation of edible film.}

The process of edible film production uses a modified method by Lopez et al. (2008) and Parra et al. (2004). A sample sago starch acetate of $5 \mathrm{~g}$ was dispersed in $80 \mathrm{~mL}$ distilled water, the solution was stirred for 15 minutes. Dispersed starch was heated at $80-85{ }^{\circ} \mathrm{C}$ for 15 minutes while stirring with a stirrer. Glycerol (1\%, w/w) and 20 $\mathrm{mL}$ of aquadest are added as plasticizers, then the suspension is reheated at $80-85^{\circ} \mathrm{C}$ for 15 minutes. The coating solution $(18 \mathrm{~g})$ is casting on acrylic plates $(\varnothing 8.5 \mathrm{~cm})$ and dried at $40{ }^{\circ} \mathrm{C}$ for 24 hours. The parameters observed were tensile strength (TS) according to ASTM D 638 (2005) and contact angle (CA) (ASTM D5946-04, 2005). Before being tested, the sample is conditioned at $27^{\circ} \mathrm{C}, 65 \% \mathrm{RH}$ for 24 hours.

\section{Statistical Analysis.}

Data from the research on the optimization of the acetylation factor for sago starch were analyzed using the response surface method (RSM). First-order experiment used a full factorial 23 with three replications at center point, namely the concentration of acetic acid anhydride/reactant $\left(\mathrm{X}_{1}=\mathrm{A}\right)$, reaction time $\left(\mathrm{X}_{2}=\mathrm{B}\right)$ and $\mathrm{pH}\left(\mathrm{X}_{3}=\mathrm{C}\right)(\mathrm{Table} 1)$ to determine effect of acetylation factors on percent acetyl, DS, TS, and CA. The second-order experiment used a 
central composite design (CCD) to determine the optimum conditions for two parameters of response to tensile strength and contact angle. Data processing was carried out with the help of Design-Expert software 7. The stages of this research can be found in Figure 1.

Table. 1:-The experimental full factorial design with three center points.

\begin{tabular}{|c|c|c|c|c|c|c|}
\hline \multirow[t]{2}{*}{ Treatments } & \multicolumn{3}{|l|}{ Actual } & \multicolumn{3}{|c|}{ Coded level* } \\
\hline & $\begin{array}{l}\text { acetic acid Anhydride } \\
(\%, \mathrm{v} / \mathrm{w} \text { starch })\end{array}$ & $\begin{array}{l}\text { Time } \\
(\min )\end{array}$ & $\mathrm{pH}$ & $\mathrm{X}_{1}$ & $\mathrm{X}_{2}$ & $\mathrm{X}_{3}$ \\
\hline 1 & 44 & 30 & 7.5 & -1 & -1 & -1 \\
\hline 2 & 88 & 30 & 7.5 & 1 & -1 & -1 \\
\hline 3 & 44 & 30 & 8.5 & -1 & -1 & 1 \\
\hline 4 & 88 & 30 & 8.5 & 1 & -1 & 1 \\
\hline 5 & 44 & 60 & 7.5 & -1 & 1 & -1 \\
\hline 6 & 88 & 60 & 7.5 & 1 & 1 & -1 \\
\hline 7 & 44 & 60 & 8.5 & -1 & 1 & 1 \\
\hline 8 & 88 & 60 & 8.5 & 1 & 1 & 1 \\
\hline 9 & 66 & 45 & 8.0 & 0 & 0 & 0 \\
\hline 10 & 66 & 45 & 8.0 & 0 & 0 & 0 \\
\hline 11 & 66 & 45 & 8.0 & 0 & 0 & 0 \\
\hline
\end{tabular}

$* \mathrm{X}_{1}=\mathrm{A}$ : Acetic acid anhydride; $\mathrm{X}_{2}=\mathrm{B}$ : reaction time; $\mathrm{X}_{3}=\mathrm{C}: \mathrm{pH}$
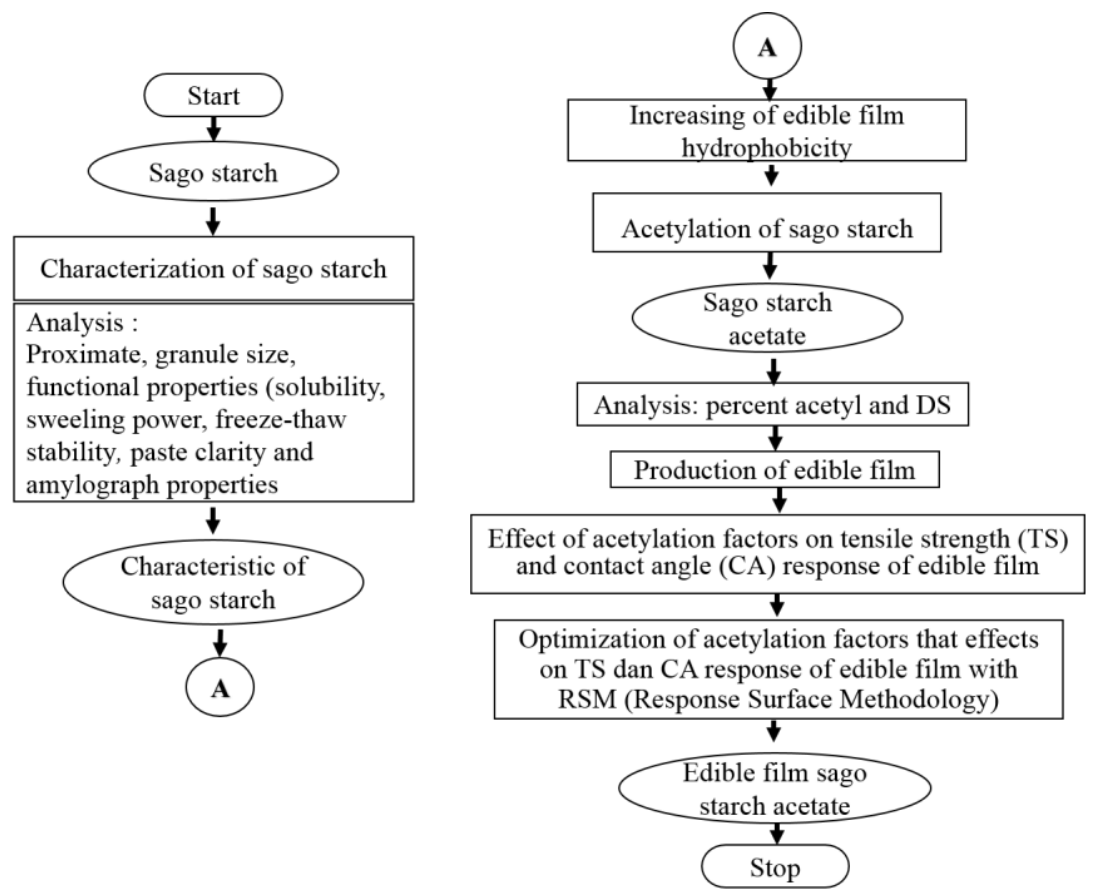

Figure 1:-The flow chart of research methodology

\section{Result and Discussion:-}

Characteristics of Sago Starch (Metroxylon sagu Rott.):-

Quality of Sago Starch (Metroxylon sagu Rott.)

The quality of native sago starch used in this study was in accordance with the SNI 01-3729-1995 and SIRIM (1972) quality standards as food ingredients except for color and crude fiber quality. The results of the quality analysis of sago starch presented in Table 2. The crude fiber content of sago starch not in accordance with quality standards as 
food ingredients but still in accordance with SIRIM-468 (1976) as an industrial ingredient which is a maximum of $1 \%$.

Table 2:-Characteristics of Sago Starch (Metroxylon sagu Rott.)

\begin{tabular}{|l|l|l|}
\hline Characteristics & Sago $\operatorname{starch}^{\mathrm{a}}$ & \multicolumn{1}{|c|}{ Standard requirement } \\
\hline Moisture (\%) & 11.82 & Max. $13^{\mathrm{b}}$ \\
\hline Ash $(\%)$ & 0.24 & Max. $0.5^{\mathrm{b}}$ \\
\hline Crude fiber (\%) & 0.25 & Max. $0.1^{\mathrm{b}}$ \\
\hline pH & 6.03 & $4.5-6.5^{\mathrm{c}}$ \\
\hline Acid total (mL NaOH 0.1N/g) & 0.20 & Max.. $4^{\mathrm{b}}$ \\
\hline Color : value & 76.62 & Min. $90^{\mathrm{cb}}$ \\
\hline Total Escherichia Coli (APM/g) & Negative & Max. $10^{\mathrm{b}}$ \\
\hline
\end{tabular}

Source: ${ }^{a}$ This study; ${ }^{b}$ SNI 01-3729 (1995); ${ }^{c}$ SIRIM standard MS 470 (1992)

\section{Physicochemical Properties of Sago Starch (Metroxylon sagu Rott.)}

The physicochemical and functional properties of native sago starch compared to some types of native starch from other sources presented in Table 3, while the granular shape can be found in Figure 2. Granule size and amylose content of sago starch were greater than rice, corn, and potato starch. The swelling power of sago starch and potato starch was greater than that of low amylose starch such as rice and corn. This is related to the larger size of the sago starch and potato granules.

The large size of starch granules indicates a high ability to absorb water when experiencing gelatinization, thus increasing the swelling power and solubility values. The high swelling power and solubility values are desirable because it can reduce paste viscosity which affects the formation of edible films when casting to produce a smooth and transparent edible film surface. Whereas starch with high amylose content greatly influences the functional properties of starch (Adebowale and Lawal, 2003). This high amylose content is very important in gelation and produces good films of starch with low amylose content (Mali et al. 2005; Bae et al. 2008).
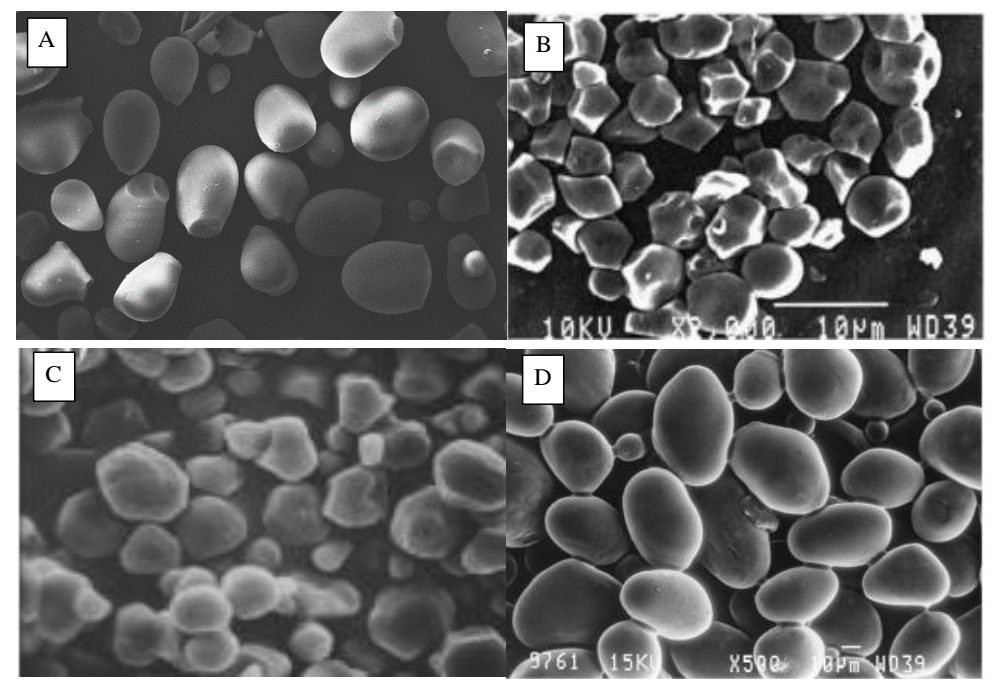

Figure 2:- Granules of native starch were measured by scanning electron microscopy (SEM) with magnification of 500 x: (A) sago starch $(30 \mu \mathrm{m})$, (B) IR-8 rice starch $(10 \mu \mathrm{m})$ (Sodhi and Singh, 2005), (C) corn starch (15 $\mu \mathrm{m})(\mathrm{Kuo}$ and Lai, 2007) and (D) potato starch $(10 \mu \mathrm{m})$ (Sandhu et al. 2015).

Fat and protein content of sago starch was greater than potato starch but smaller than rice and corn starch. Fat and protein content are minor components of starch, but these minor components greatly determine the functional properties of starch. Both of these minor compositions will form a hydrophobic layer on the surface of starch granules causing inhibition of starch granule swelling so that the value of solubility and swelling power of rice and 
corn starch is low. This makes the viscosity of paste higher and has an impact on the formation of the film (filmforming) when casting because it will form a thick film, rough surface and not transparent (opaque).

Table 3:-The physicochemical, functional properties of sago starch (Metroxylon sagu Rott.) and several types of starch

\begin{tabular}{|l|c|c|c|c|}
\hline Physicochemical properties & ${\text { Sago } \text { starch }^{\mathrm{a}}}$ & Rice $^{\mathrm{b}}$ & Corn $^{\mathrm{c}}$ & Potatoes $^{\mathrm{d}}$ \\
\hline Size of starch granule $(\mu \mathrm{m})$ & $30.82-51.14$ & $4-7.2$ & $4-18$ & $5-110$ \\
\hline Amylose $(\%)$ & 38.79 & 29.70 & 27.6 & 18.60 \\
\hline Fat $(\%)$ & 1.38 & 0.85 & 0.79 & 0.08 \\
\hline Protein $(\%)$ & 1.50 & 0.71 & 0.42 & 0.08 \\
\hline Solubility at $70{ }^{\circ} \mathrm{C}(\%)$ & 15.44 & 1.74 & 8.50 & 13.70 \\
\hline Swelling power at $70{ }^{\circ} \mathrm{C}(\%)$ & 32.57 & 5.93 & 15.15 & 44.10 \\
\hline Clarity of paste $1 \%(\% \mathrm{~T})$ & 74.76 & - & - & - \\
\hline Freeze-thaw stability $(\%$ syneresis) & 83.42 & - & - & - \\
\hline
\end{tabular}

Source : ${ }^{a}$ This study; ${ }^{b}$ Gonzales dan Perez (2002); ${ }^{c}$ Kuo dan Lai (2007); ${ }^{\mathrm{d}}$ Sandhu et al. (2015)

\section{Amylographic Properties of Sago Starch (Metroxylon sagu Rott.)}

Amylographic properties of the native sago starch are presented in Table 4. Based on observations of the sago starch gelatinization temperature at $74.1{ }^{\circ} \mathrm{C}$ (Table 4) as indicated by pasting temperature parameters, the gelatinization temperature of sago starch was relatively the same as the results of Polnaya's research (2008). When sago starch gelatinized, it will begin to increase the viscosity of the sago starch granules which are irreversible. As a result, when sago starch gelatinized, maltose cross (birefiregrance) from the sago starch granules will disappear (Kusnandar 2010). At the time of gelatinization, the amylose starch structure will begin to diffuse out of the granule due to the breaking of the hydrogen bond between amylose and amylopectin. This will be followed by an increase in viscosity to its peak so that the structure of the sago starch granules will break, forming a paste.

Table 4:- Amylographic parameters of sago starch (Metroxylon sagu Rott.)

\begin{tabular}{|l|c|c|c|c|}
\hline Parameters & Sago starch $^{\mathrm{a}}$ & Rice $^{\mathrm{b}}$ & Corn $^{\mathrm{c}}$ & Potatoes $^{\mathrm{d}}$ \\
\hline Pasting temperature $\left({ }^{0} \mathrm{C}\right)$ & 74.10 & 71.86 & 83.15 & 67.0 \\
\hline Peak viscosity $(\mathrm{cP})$ & 6288 & 2583 & 1801 & 4596 \\
\hline Breakdown viscosity (cP) & 1856 & 682 & 881 & 1468 \\
\hline Final viscosity (cP) & 3502 & 3190 & 1654 & 3943 \\
\hline Setback (cP) & 1646 & 1289 & 734 & 815 \\
\hline
\end{tabular}

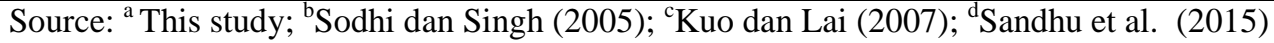

Sago starch has higher final viscosity (3502 cP, Table 4) than rice and corn starch and lower than potatoes. Starch which is high in amylose content generally has a higher final viscosity (viscosity at $50{ }^{\circ} \mathrm{C}$ ) and can be used as raw material for gelling and film to be used as raw material for making vermicelli and noodles (Winger et al. 2014), while starch the high amylopectin content will have a lower viscosity (viscosity at $50{ }^{\circ} \mathrm{C}$ ) making it suitable for thickening agents (Trappey et al. 2015).

Optimization of Acetylation Factors of Sago Starch (Metroxylon sagu Rott) on Edible Film Characteristics:Effect of Acetylation Factors on Percent Acetyl and Degree of Substitution (DS) of Sago Starch Acetate Percent acetyl and degree of substitution (DS) of sago starch from acetylation respectively ranged from 1.94 to 5.75 and 0.07 to 0.23 . The DS value of acetate starch was in accordance with the standards for commercial starch (Boutboul et al. 2002; Matti et al. 2004). Analysis of variance (ANOVA) (Table 5) results showed that the concentration of acetic acid anhydride/reactant (A), reaction time (B), $\mathrm{pH}(\mathrm{C})$ and interaction between reaction reactant concentrations had a significant effect on $\mathrm{P}<0.05$ and $\mathrm{P}<0.1$ to acetyl percent and DS. The coefficient of determination $\left(\mathrm{R}^{2}\right)$ for these two responses was $99.12 \%$ and $99.82 \%$, respectively, indicating that the level of suitability of the experimental results matches the mathematical model. The equation factorial design for the percent acetyl and DS values as follows:

Percent acetyl $(\%)=3.92+1.38 \mathrm{~A}+0.30 \mathrm{~B}+0.29 \mathrm{C}+0.06 \mathrm{AB}-0.13 \mathrm{AC}-0.01 \mathrm{BC}-0.06 \mathrm{ABC}$

$\mathrm{DS}=0.15+0.06 \mathrm{~A}+0.01 \mathrm{~B}+0.01 \mathrm{C}+0.001 \mathrm{AB}-0.006 \mathrm{AC}+0.001 \mathrm{BC}-0.001 \mathrm{ABC}$ 
Table 5:- Regression coefficient and significance of full factorial design for percent acetyl and DS responses of sago starch acetate

\begin{tabular}{|l|c|c|c|c|}
\hline \multirow{2}{*}{ Factors } & \multicolumn{2}{|c|}{ Coefficient } & \multicolumn{2}{c|}{ Significance (\%) } \\
\cline { 2 - 5 } & Percent Acetyl & DS & Percent Acetyl & DS \\
\hline Intercept & 3.923 & 0.154 & 96.91 & 99.18 \\
\hline A- Acetic acid anhydride & 1.375 & 0.056 & 99.51 & 99.87 \\
\hline B- Time & 0.303 & 0.014 & 91.08 & 97.87 \\
\hline C- pH & 0.285 & 0.011 & 90.11 & 96.86 \\
\hline AB & 0.060 & 0.001 & 40.08 & 39.74 \\
\hline AC & -0.128 & -0.006 & 68.09 & 90.78 \\
\hline BC & -0.010 & 0.001 & 7.27 & 39.74 \\
\hline ABC & -0.057 & -0.001 & 38.67 & 39.74 \\
\hline
\end{tabular}

Equations 1 and 2 show that the percent acetyl and DS increases directly with the increase in the amount of reactant concentration and $\mathrm{pH}$ value indicated by positive constants. The higher the concentration of reactants and the $\mathrm{pH}$ value results in high percent acetyl and DS value. The high concentration of reactants will increase the chances of collisions between molecules so that the acetylation process is easier to occur. In addition, the acetylation process in starch is a nucleophile one (SN1) substitution, where the process is strongly influenced by the strength of the acetyl group as a nucleophile component. This substitution process requires a base catalyst to make the acetyl group which will substitute stronger. While the length of reaction time does not significantly affect on the two values. The results of this study were the same as those reported by Mark et al. (1969) that DS values increased with increasing reactant concentrations of up to $88 \%$ with DS values of 0.26 and produced good mechanical properties on edible films made from corn starch. The $\mathrm{pH}$ value (8 - 8.5) was the best condition for producing acetyl and DS values of acetate corn starch Betancur et al. 1997 and Xu et al. 2004).

\section{Effect of Acetylation Factors on Tensile Strength of Edible Film}

Edible films produced from the acetylation of sago starch produce tensile strength (TS) values ranging from 1.23 4.08 MPa. This TS of the edible film was influenced by the concentration of reactants and $\mathrm{pH}$. The ANOVA of a full factorial design results for TS edible film sago starch acetate presented in Table 6. Based on the results of the regression analysis the determination coefficient $\left(\mathrm{R}^{2}\right) \mathrm{TS}$ was $96.79 \%$, this shows that the equation for TS response (Equation 3) has a degree of conformity high with experimental data. From the ANOVA test, we obtained the regression equation model:

$\mathrm{TS}=2.041-0.65 \mathrm{~A}-0.04 \mathrm{~B}-0.29 \mathrm{C}$

As shown in Table 6, TS response decreased along with the increased in reactant concentration indicated by a negative coefficient of -0.65 with a significance of $97.88 \%(\mathrm{p}<0.05)$ and a reaction $\mathrm{pH}$ of -0.29 with a significance of $90.71 \%$ ( $\mathrm{p}<0.1$ ). The higher the concentration of reactants and reaction $\mathrm{pH}$ will produce a low TS value, this is related to percent acetyl and DS produced from the acetylation process. Percent acetyl and DS of sago starch acetate were strongly influenced by the concentration of reactants (Table 6). The higher the concentration of reactants the greater the two values. Percent acetyl and DS value ranged from 0.07 to 0.27 , the value of which increased from both parameters will reduce the TS of edible film properties because there is an acetyl group in acetate sago starch. The acetyl group will prevent bonding between molecules and $\mathrm{OH}$ groups. The results of the same study were reported by Colussi et al. (2017) that the acetylation of starch with acetic acid anhydride increases the value of DS which has an impact on low tensile strength (TS) of edible films. The acetylation process of sago starch decreases the elasticity of the edible film. Edible films of methylated sago starch become less flexible or easier to break. The lower the TS value, the more the material is brittle. The process of substitution of the hydroxyl $(\mathrm{OH})$ group to the acetyl group has reduced the elasticity of the material. This decrease in TS value is due to the acetyl group has greater molecular weight and more molecular shape compared to $\mathrm{OH}$. Acetyl which enters sago starch makes sago starch denser and harder which results in a decrease in elasticity. 
Table 6:-Regression coefficient and significance of full factorial design for tensile strength response of the edible film

\begin{tabular}{|l|c|c|}
\hline Factors & Coefficient & Significance (\%) \\
\hline Intercept & 2.04 & 89.21 \\
\hline A-Anhydride acetic acid & -0.65 & 97.88 \\
\hline B-time & -0.04 & 30.80 \\
\hline C-pH & -0.29 & 90.71 \\
\hline AB & -0.02 & 11.94 \\
\hline AC & 0.21 & 84.24 \\
\hline BC & 0.01 & 6.46 \\
\hline ABC & -0.03 & 24.23 \\
\hline
\end{tabular}

Effect of Acetylation Factors on Contact Angle of Edible Film

The contact angle was measured to determine the hydrophobicity of edible film. The measurement results of the contact angle (CA) of edible film acetate sago starch ranged from $27.22-56.440$. This CA value of the edible film is influenced by the concentration of reactants and the $\mathrm{pH}$ of the reaction. The ANOVA of a full factorial design results for CA edible film sago starch acetate presented in Table 7. The coefficient of determination (R2) CA was $98.90 \%$, this indicates that the equation for CA response (Equation 4) has a high degree of conformity with experimental data. From the ANOVA test we obtained the regression equation model:

$\mathrm{CA}=41.74+10.46 \mathrm{~A}+1.71 \mathrm{~B}+2.46 \mathrm{C}$

Table 7:- Regression coefficient and significance of full factorial design for contact angle response of the edible film

\begin{tabular}{|l|c|c|}
\hline Factors & Coefficient & Significance (\%) \\
\hline Intercept & 41.74 & 96.20 \\
\hline A-Anhydride acetic acid & 10.46 & 99.40 \\
\hline B-Time & 1.71 & 82.10 \\
\hline C-pH & 2.46 & 90.10 \\
\hline AB & -1.24 & 72.10 \\
\hline AC & -2.10 & 87.00 \\
\hline BC & 1.34 & 74.60 \\
\hline ABC & -1.12 & 68.40 \\
\hline
\end{tabular}

As shown in Table 7, the concentration of reactants has a very positive effect on CA values of edible film with a oefficient value of 10.46 and a significance of $99.4 \%(\mathrm{p}<0.05$ ), as well as $\mathrm{pH}$, has a positive effect on CA values of edible film with a coefficient of 1.71 and significance $82.1 \%(\mathrm{p}<0.1)$. The higher the concentration of reactants and $\mathrm{pH}$ the greater the CA value of the edible film. The CA value of the edible film was influenced by the magnitude of the DS value, the DS value also affects the tensile strength of edible film 'previously described. Acetyl percent and DS of acetate starch were strongly influenced by the concentration of reactants (Table 5). High DS values indicate the number of $\mathrm{OH}$ groups in sago starch substituted with acetyl groups in the acetylation process. The results of the same study were reported by Chi et al. (2008) that the acetylation process can increase the CA value of native corn starch, this can change the level of the polarity of the starch with values of DS and CA obtained 2.89 and $68.2^{\circ}$. Zhou et al (2016) reported that acetylation drastically changed the surface of cellulose powder from hydrophilic properties to hydrophobic with a DS value of 0.14 resulting in a CA value of $44^{\circ}$ and a DS value of 2.62 yieldings CA $132^{\circ}$ edible film cellulose acetate. Modification of starch can increase the hydrophobicity of edible film (Figure $3)$. The entry of the acetyl group on starch converts the starch's polarity more towards hydrophobicity. The acetyl group $\left(\mathrm{CH}_{3} \mathrm{COO}\right)$ is less polar when compared to the $\mathrm{OH}$ group that has been replaced. The more $\mathrm{OH}$ groups substituted, the more starch the hydrophobic properties will be. The difference in polarity will make a greater interaction between starch and measuring surface resulting in a greater contact angle. 

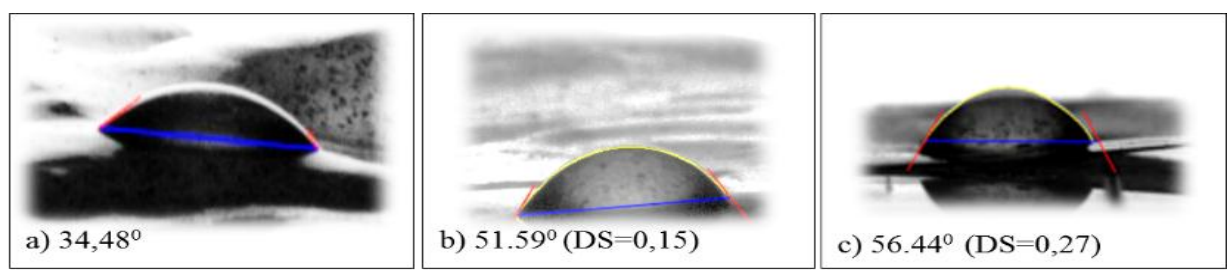

Figure 3:- Contact angle on the appearance of native sago starch edible film (a), sago starch acetate of DS 0.15 (b) and DS 0.27 (c).

Optimization of Acetylation on Tensile Strength and the Contact Angle Properties Responses of Edible film:Results of analysis of variance (ANOVA) in Table 5 and Table 7 showed that the reaction time had no effect on TS and CA of edible film properties with significance of $30.80 \%$ ( $>0.05$ and $82.10 \%$ ( $>0.05$ ), then the reaction time factor was eliminated for second-order RSM analysis with CCD (Central Composite Design) (Table 8). Contour plots of TS and CA of edible film test results with response surface methodology can be seen in Figure 4. Contour plot TS (Figure 4a) of the edible film showed that the greater concentration of reactants and $\mathrm{pH}$, the lower TS value, but increases CA value (Figure $4 \mathrm{~b}$ ) of edible film. Results of ANOVA found of the determination coefficient $\left(\mathrm{R}^{2}\right)$ TS of $75.64 \%$ and CA of $98.19 \%$ showed that the equations for TS (Equation 5) and CA (Equation 6) of edible film responses had a high degree of conformity with experimental data. Quadratic model equations for TS and CA of edible film responses:

$\mathrm{TS}=1.73-0.56 \mathrm{~A}-0.14 \mathrm{C}+0.18 \mathrm{AC}+0.65 \mathrm{~A}^{2}+0.04 \mathrm{C}^{2}$

$\mathrm{CA}=51.12+8.47 \mathrm{~A}+4.02 \mathrm{C}-3.21 \mathrm{AC}-2.83 \mathrm{~A}^{2}-4.78 \mathrm{C}^{2}$

Table 8:- Responses of the tensile strength (TS) and contact angle (CA) of edible film from central composite design (CCD)

\begin{tabular}{|l|c|c|c|c|c|c|}
\hline \multirow{3}{*}{ Treatments } & \multicolumn{2}{|c|}{ Actual } & \multicolumn{2}{c|}{ Coded level $^{*}$} & \multicolumn{2}{c|}{ Response } \\
\cline { 2 - 7 } & $\begin{array}{c}\text { acetic acid } \\
\text { Anhydride } \\
\text { \%, v/w starch })\end{array}$ & $\mathrm{pH}$ & $\mathrm{X}_{1}$ & $\mathrm{X}_{3}$ & $\mathrm{TS}$ & \\
\hline 1 & 44 & 7.5 & -1 & -1 & 3.12 & 27.22 \\
\hline 2 & 88 & 7.5 & 1 & -1 & 1.44 & 52.09 \\
\hline 3 & 44 & 8.5 & -1 & -1 & 2.2 & 41.24 \\
\hline 4 & 88 & 8.5 & 1 & -1 & 1.23 & 53.26 \\
\hline 5 & 34.9 & 8.0 & -1.414 & 0 & 4.08 & 34.62 \\
\hline 6 & 97.1 & 8.0 & 1.414 & 0 & 2.8 & 56.44 \\
\hline 7 & 66 & 7.3 & 0 & -1.414 & 2.21 & 35.64 \\
\hline 8 & 66 & 8.7 & 0 & 1.414 & 2.23 & 47.62 \\
\hline 9 & 66 & 8.0 & 0 & 0 & 2.04 & 48.54 \\
\hline 10 & 66 & 8.0 & 0 & 0 & 1.63 & 53.23 \\
\hline 11 & 66 & 8.0 & 0 & 0 & 1.53 & 51.59 \\
\hline
\end{tabular}

$\mathrm{X}_{1}=\mathrm{A}:$ Acetic acid anhydride; $\mathrm{X}_{3}=\mathrm{C}: \mathrm{pH}$

The determination of the optimum formula was determined based on superimposed contour plots from the parameters of tensile strength and contact angle of edible film using Design-Expert software. The optimization value was done using the maximum value criteria for TS and CA of edible film responses. The optimum formula area obtained can be seen from the superimposed results of combining contour plots of each parameter used for optimization (Figure 5). Superimposed graphs obtained show areas that provide optimum response according to the desired goal.

The optimum area can change depending on the goal of the desired edible film properties. The process conditions with anhydride acetic acid concentration of $44 \%$ and $\mathrm{pH} 8.24$ and 60 minutes reaction time are recommended as optimal formula solutions with high desirability values. This combination results in a tensile strength value of 2.80 $\mathrm{MPa}$ and contact angle of $42.18^{\circ}$ of edible film sago starch acetate. 

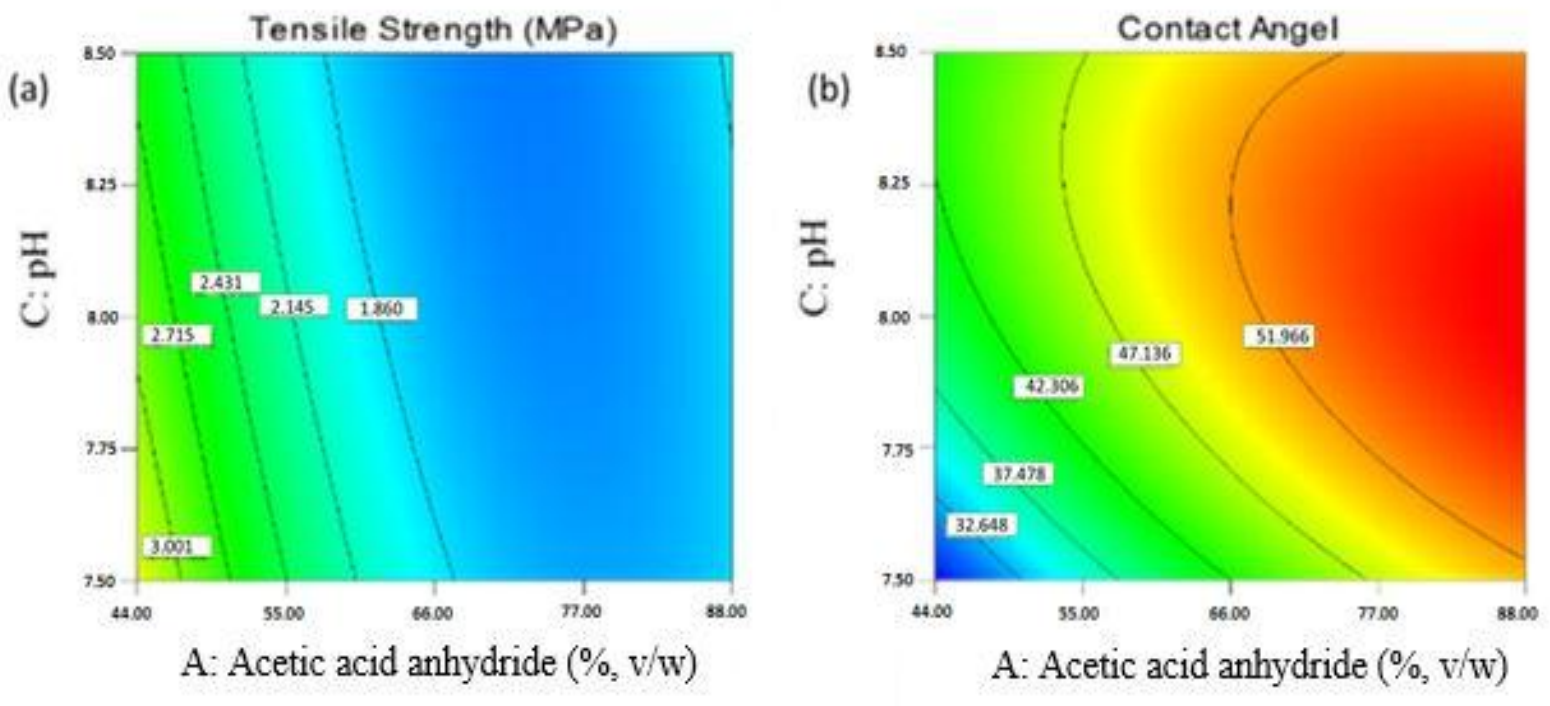

Figure 4:-Contour plot profile: (a) tensile strength and (b) contact angle of edible film

Design-Expert $\circledast$ Softw are

Overlay Plot

Tensile Strength

Contct Angle

$\mathrm{X}_{1}=\mathrm{A}$ : Acetic acid anhydride $\mathrm{X}_{3}=\mathrm{C}: \mathrm{pH}$

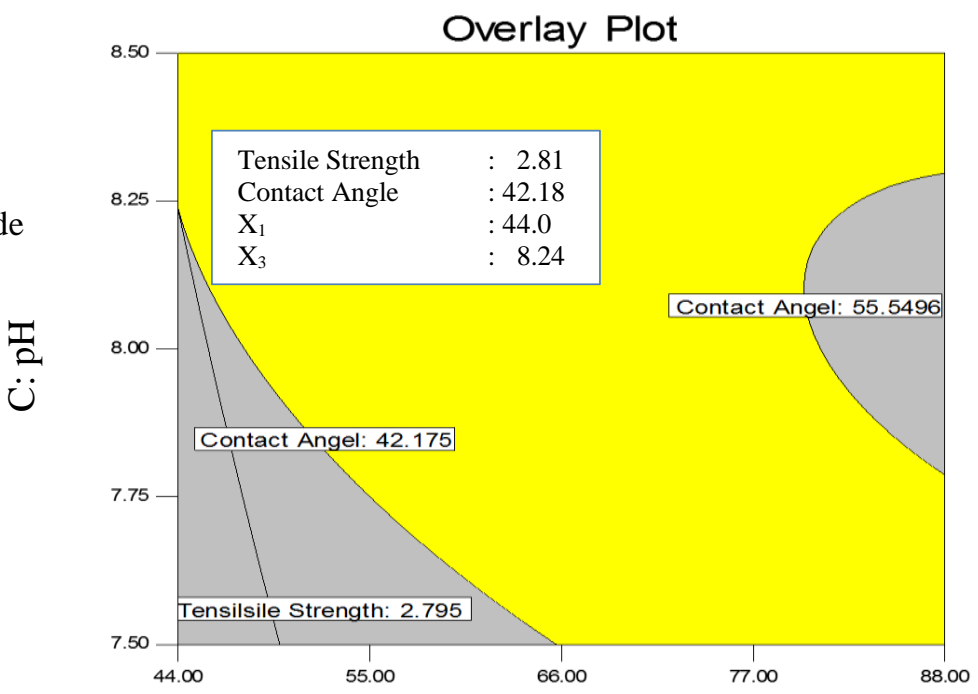

A: Acetic acid anhydride (\%, v/w)

Figure 5:-Superimpose contour plot graph for tensile strength and hydrophobicity (contact angle) properties of edible film sago starch acetate at optimum conditions.

\section{Validation of Optimum Condition}

To validate the model under optimal conditions, this formulation was tested in three replications. Validation results showed that the concentration of $44 \%$ acetic acid anhydride and $\mathrm{pH} 8.24$ and reaction time of 60 minutes obtained a percent acetyl $(3.54 \% \pm 0.25)$, DS $(0.14 \pm 0.01)$ value, this process conditions produced the experiment values of TS $(2.80 \pm 0.17)$ and CA $\left(49.78^{\circ} \pm 0.75\right)$ of edible film was found to be similar to the model prediction value. The difference in value between the experiment and optimum values was $0 \%$ for TS and $13.5 \%$ CA. The optimization model was acceptable because of the experiment value in accordance with the model prediction. The TS and CA 
response values of edible film meet the $95 \%$ confidence interval that the program presents. The results of predictions and validation values of responses at optimum conditions of the acetylation process can be seen in Table 9 .

Table 9:- Predicted and experimental values of responses at optimum conditions

\begin{tabular}{|c|c|c|c|c|c|c|}
\hline \multicolumn{2}{|c|}{ Factors } & \multicolumn{4}{|c|}{ Responses } \\
\cline { 2 - 7 } & \multicolumn{2}{|c|}{ Predicted value } & \multicolumn{2}{c|}{ Experimental value (n=3) } \\
\hline $\begin{array}{c}\text { acetic acid } \\
\begin{array}{c}\text { Anhydride } \\
(\%, \mathrm{v} / \mathrm{w} \\
\text { starch })\end{array}\end{array}$ & $\mathrm{pH}$ & $\begin{array}{c}\text { Tensile Strength } \\
(\mathrm{Mpa})\end{array}$ & $\begin{array}{c}\text { Contact Angle } \\
\left({ }^{\circ}\right)\end{array}$ & $\begin{array}{c}\text { Degree of } \\
\text { Substitution (DS) }\end{array}$ & $\begin{array}{c}\text { Tensile } \\
\text { Strength } \\
(\mathrm{MPa})\end{array}$ & $\begin{array}{c}\text { Contact Angle } \\
\left({ }^{0}\right)\end{array}$ \\
\hline 44 & & & & & & \\
\hline
\end{tabular}

\section{Conclusion:-}

The quality of native sago starch was in accordance with SNI 01-3729-1995 and SIRIM quality standards (1972). Native sago starch had $38.79 \%$ amylose content and functional properties, namely, the solubility of $15.44 \%$, swelling power of $32.57 \%$, paste clarity of $74.76 \%$ and freeze-thaw stability of $83.42 \%$. The final viscosity of 3502 suitable as an ingredient in making edible films. The concentration of acetic acid anhydride and $\mathrm{pH}$ greatly influenced the properties of TS and CA of the edible film with significance values for TS of $97.88 \%$ and $90.71 \%$ and CA of $99.40 \%$ and $90.10 \%$, respectively. The quadratic model for TS $=1.73-0.56 \mathrm{~A}-0.14 \mathrm{C}+0.18 \mathrm{AC}+$ $0.65 \mathrm{~A}^{2}+0.04 \mathrm{C}^{2}$ with $\mathrm{R}^{2}=75.64 \%$ and for $\mathrm{CA}=51.12+8.47 \mathrm{~A}+4.02 \mathrm{C}-3.21 \mathrm{AC}-2.83 \mathrm{~A}^{2}-4.78 \mathrm{C}^{2}$ with $\mathrm{R}^{2}=$ $98.19 \%$. The optimum condition for acetylation is the concentration of acetic acid anhydride $44 \%$ and $\mathrm{pH} 8.24$ and a reaction time of 60 minutes. This combination results in tensile strength of $2.80 \mathrm{MPa}$ and contact angle of $42.18^{\circ}$ value of edible film sago starch acetate.

\section{Acknowledgment:-}

The author would like to thank the Agricultural Research and Development Agency, Ministry of Agriculture, Indonesia for funding this research.

\section{References:-}

1. Abner L, Miftahorrahman. 2002. Keragaman Industri Sagu Indonesia. Warta Penelitian dan Pengembangan Tanaman Industri. 8(1), 2002.

2. Adebowale KO, and Lawal OS. 2003. Functional properties and retrogradation behaviour of native and chemically modified starch of mucuna bean (Mucuna pruriens). J Sci Food and Agric, 83, 1541-1546

3. AOAC, 1995. Official Methods of Analysis of AOAC International, 2v (16 ed.). Arlington, TX: Association of Official Analytical Chemistry.

4. Bae HJ, Cha DS, Whiteside WS, Park HJ. 2008. Film and pharmaceutical hard capsuleformation properties of mungbean, waterchestnut, and sweet potato starches. Food Chem. 106(1): 96-105.

5. Baldwin EA. 1994. Edible coatings for fresh fruits and vegetables: past, present, and future. In: Krochta JM, Baldwin EA, Nisperos-Carriedo MO, editors. Edible coatings and films toimprove food quality. Lancaster, Pa.: Technomic Publishing Co., Inc. p 25-64.

6. Chi H, Xu K, Wu X, Chen Q, Xue D, Song C, Zhang W, Wang P. 2008. Effect of acetylation on the properties of corn starch. Food Chem. 106(2008), 923-928.

7. Colussi R, Pinto V Z, El Halal SLM, Vanier NL, Villanova FA, Marques E Silva R, Dias ARG. 2014. Structural, morphological, and physicochemical properties of acetylated high-, medium-, and low-amylose rice starches. Carbohydr Polym. 103(1), 405-413.

8. Gonzales Z, Perez E. 2002. Effect of acetylation on some properties of rice starch. Starch. 54: 148-154, 2002 packaging and preservation. London, U.K.: Elsevier Applied Science Publishers. p 371-94.

9. Guilbert S. 1986. Technology and application of edible protective films. In: Mathlouthi M, editor. Food packaging and preservation. London, U.K.: Elsevier Applied Science Publishers. p 371-94.

10. Huang J, Schols HA, Jin Z, Sulmann E, Voragen AGJ. 2007. Pasting properties and (chemical) fine structure of acetylated yellow pea starch is affected by acetylation reagent type and granule size. Carbohydr Polym. 68: 397406.

11. Karim AA, Tie AP, Manan DMA, Zaidul ISM. 2008. Starch from the Sago (Metroxylon sagu) Palm Tree Properties, Prospects, and Challenges as a New Industrial Source for Food and Other Uses, (1977).

12. Kester J, Fennema O. 1986. Edible films and coatings: a review. Food Technol. 40:47-59.

13. Kusnandar F. 2010. Kimia Pangan Komponen Makro. Seri 1. Dian Rakyat, Jakarta 
14. Kuo WY, Lai HM. 2007. Changes of property and morphology of cationic corn starches. Carbohydr Polym. 69(3), 544-553.

15. Mali S, Grossmann, MVE, García MA, Martino MN, Zaritzky NE. 2005. Mechanical and thermal properties of yam starch films. Food Hydrocolloids, 19: 157-164.

16. Matti E, Tomas A, Pasi S, Reino L, Soili P, Sari H. 2004. Determination of the degree of substitution of acetylated starch by hydrolysis, 1H NMR and TGA/IR. Carbohydr Polym. 57: 261-267.

17. Oates CG, Hicks A. 2002. Sago starch production in Asia and the Pacific-problems and prospects. In: Proceedings of the International Symposium on Sago (Sago 2001) held on October 15-17 2001, at the Tsukuba International Congress Center Japan. Universal Academy Press Inc., Tokyo, p. 27-36.

18. Perez LAB, Acevedo EA, Hernandez LS dan O.P. Lopez. 1999. Isolation and Partial Characterization of Banana Starches. J. Agric. Food Chem. $47: 854-857$

19.Polnaya FJ, Talahatu J, Haryady, Marseno DW. 2009. Karakterisasi tiga jenis pati sagu (metroxylon sp.) hidroksipropil. Agritech, 29(2), 87-95.

20. Sandhu KS, Sharma L, Kaur, M. 2015. Effect of granule size on physicochemical, morphological, thermal and pasting properties of native and 2-octenyl-1-ylsuccinylated potato starch prepared by dry heating under different pH conditions. LWT - Food Sci Technol. 61(1), 224-230.

21.SIRIM, 1992. Malaysian Standard MS 470: specification for edible sago starch.

22. Sodhi NS, Singh N. 2005. Characteristics of acetylated starches prepared using starches separated from different rice cultivars. J. Food Eng. 70(2005), pp.117-127.

23. Sun R, Sun XF. 2002. Structural and thermal characterization of acetylated rice, wheat, rye, and barley straws and poplar wood fibre. Ind Crops Prod. 16(3): 225-235.

24. Trappey EF, Khouryieh H, Aramouni F, Herald T. 2015. Effect of sorghum flour composition and particle size on quality properties of gluten-free bread. Food Sci Technol Int. 21(3): 188-202.

25. Tupa MV, Ramírez JAA, Vázquez A, Foresti MA. 2015. Organocatalytic acetylation of starch: effect of reaction conditions on DS and characterisation of esterified granules. Food Chem. 170: 295-302.

26. Winger M, Khouryieh H, Aramouni F, Herald TJ. 2014. Sorghum flour characterization and evaluation in glutenfree flour tortilla. J Food Quality. 37(2): 95-106.

27. Wurzburg OB. 1964. Acetylation. In Methods in Carbohydrate Chemistry; Whisther, RL, Smith, RJ, Wolfrom, M L, Eds.; Academic Press: New York, 1964.; Vol IV, pp 240- 241.

28.Zhou X, Lin X, White KL, Lin S, Wu H, Cao S, Chen L. 2016. Effect of the degree of substitution on the hydrophobicity of acetylated cellulose for production of liquid marbles. Cellulose, 23(1), 811-821. 